\title{
Technology-facilitated sexual violence: a review of virtual violence against women
}

\author{
Violência sexual facilitada por tecnologia: uma revisão da violência virrtual contra a mullher \\ Violencia sexual facilitada por la tecnología: una revisión de la violencia virtual contra las mujeres
}

Received: 01/14/2022 | Reviewed: 01/20/2022 | Accept: 02/04/2022 | Published: 02/06/2022

Ana Valentina Medeiros de Araújo
ORCID: https://orcid.org/0000-0003-1999-1046
University of Pernambuco, Master in Forensic Science, Brazil
E-mail: ana.valaraujo @ gmail.com
Cristine Vieira do Bonfim
ORCID: https://orcid.org/0000-0002-4495-9673
Joaquim Nabuco Foundation/ University of Pernambuco, Postgraduate Program in Collective Health, Brazil
E-mail: cristine.bonfim@uol.com.br
Magaly Bushatsky
ORCID: https://orcid.org/0000-0002-0792-6469
University of Pernambuco, Master in Forensic Science, Brazil
E-mail: magalybush@gmail.com
Betise Mery Alencar Furtado
ORCID: https://orcid.org/0000-0001-6344-8257
University of Pernambuco, Master in Forensic Science, Brazil
E-mail: betisemery@gmail.com

\begin{abstract}
With the modernization of technology, new virtual forms of violence have emerged and old ways of perpetrating violence against women have been exacerbated with the use of the internet and social networks. This study aimed to investigate the forms of violence against women on the internet. This is an integrative literature review of the electronc databases SciVerse Scopus, Medical Literature Analysis and Retrieval System Online and Scientific Electronic Library Online. The inclusion criteria were publications that occurred in the time span from January 2016 to July 2021, with the descriptors "Violence," "Internet," "Woman," "Gender," "Sexual Violence," "Sexual Harassment," "Intimate Partner Violence," and "Internet and Abuse". As a result of the review, 30 articles were selected. Nine categories of violence against women on the Internet were identified, included in the concept of sexual violence facilitated by technology, in addition to digital dating abuse and cyberbullying. The most commonly addressed categories were digital dating abuse, revenge porn, sexting, and online misogyny. Most of the studies found concluded greater online victimization for women than for men in all categories except cyberbullying.
\end{abstract}

Keywords: Violence against women; Internet; Gender; Intimate partner violence; Sexual harassment.

\begin{abstract}
Resumo
Com a modernização da tecnologia, novas formas virtuais de violência surgiram e antigos meios de perpetração de violência contra a mulher foram exacerbados com o uso da internet e redes sociais. Este estudo teve como objetivo investigar as formas de violência contra a mulher na internet. Trata-se de uma revisão integrativa da literatura das bases de dados eletrônicas SciVerse Scopus, Medical Literature Analysis and Retrieval System Online e Scientific Electronic Library Online. Os critérios de inclusão foram publicações ocorridas no espaço temporal de janeiro de 2016 a julho de 2021, com os descritores "Violência", "Internet", "Mulher", "Gênero", "Violência Sexual", "Assédio Sexual", "Violência por Parceiro Íntimo" e "Internet e Abuso". Como resultado da revisão, foram selecionados 30 artigos. Foram identificadas nove categorias de violência contra a mulher na internet, inclusas no conceito de violência sexual facilitada por tecnologia, além do abuso digital de namoro e cyberbullying. As categorias mais abordadas foram o abuso digital de namoro, pornografia de vingança, sexting e misoginia online. A maior parte dos estudos encontrados concluiu pela maior vitimização online para as mulheres do que para os homens em todas as categorias, com exceção do cyberbullying.
\end{abstract}

Palavras-chave: Violência contra a mulher; Internet; Gênero; Violência por parceiro íntimo; Assédio sexual.

\section{Resumen}

Con la modernización de la tecnología, han surgido nuevas formas virtuales de violencia y se han exacerbado las viejas formas de perpetrar la violencia contra las mujeres con el uso de internet y redes sociales. Este estudio tiene como objetivo investigar las formas de violencia contra las mujeres en internet. Se trata de una revisión bibliográfica integradora de las bases de datos electrónicas SciVerse Scopus, Medical Literature Analysis and Retrieval System Online y Scientific Electronic Library Online. Los criterios de inclusión fueron las publicaciones ocurridas en el espacio temporal de enero de 2016 a julio de 2021, con los descriptores "Violencia", "Internet", "Mujer", "Género", 
"Violencia sexual", "Acoso sexual", "Violencia de pareja" e "Internet y abuso". Como resultado de la revisión, fueron seleccionados 30 artículos. Fueron identificadas nueve categorías de violencia contra las mujeres en internet, incluidas en el concepto de Violencia Sexual Facilitada por la Tecnología, además del abuso en las citas digitales y el ciberacoso. Las categorías más abordadas fueron el abuso en las citas digitales, la pornografía por venganza, el sexting y la misoginia en línea. La mayoría de los estudios concluyeron en una mayor victimización en línea para las mujeres que para los hombres en todas las categorías, con la excepción del ciberacoso.

Palabras clave: Violencia contra la mujer; Internet; Género; Violencia de pareja; Acoso sexual.

\section{Introduction}

The Internet is a global phenomenon of exponential growth and is characterized by the rise of information in human practices and the use of Information and Communication Technologies (ICT) in everyday life (Zúñiga et al., 2018). ICT's correspond to transmission and telecommunications systems, telecommunications services (wireless, mobile, fixed), computer hardware, content production and management of multimedia systems, networks and services, mobile device applications, and internet technologies (Medeiros et al., 2021).

Worldwide, between 2000 and 2020, there has been a 577\% growth in the number of internet users worldwide of $577 \%$ compared to the numbers in 2000 (Naseri et al., 2021). The intense use of the virtual environment, with the proliferation of communication technologies, has caused a transformation in romantic and sexual relationships and the emergence of new forms of violence (Hobbs et al., 2017), among which violence against women on the internet stands out.

The World Health Organization defines violence as the "intentional use of physical force or power, or actual or threatened power, against oneself, another person, or against a group or community" (Minayo, 2020). Manifestations of violence can be mechanical physical, psychological, sexual, or even take the form of economic violence (Tetikcok et al., 2016).

Violence against women, in turn, is considered a global public health problem (Sánchez et al., 2020) and was framed by the United Nations as gender violence in the Declaration on the Elimination of Violence against Women (United Nations, 1993). This declaration, although not binding, aimed to strengthen the commitments of national states with global participation and formulation of policies to combat violence against women (Agarwal, 2021). It has a strong foundation in the feminist analysis of the existing social inequality between men and women, present on a large scale in every society; in this sense, the UN identifies the family, the community and the State as the main places where violence against women is observed (Montesanti, 2015).

Gender-based violence can include domestic violence (physical, sexual, economic, and psychological), sexual harassment, sexual assault, and rape (Skinner et al., 2021; Montesanti, 2015). The relevance of the framework made by the UN lies in the understanding that violence is somehow influenced by or influences gender relations (Skinner et al., 2021).

After 1993, some states adopted specialized legislation aimed at preventing and punishing violence against women. These laws, however, have failed to effectively stop these forms of violence and harassment, which remain commonplace. In some cases, the main challenge is to align behavior with the letter and spirit of progressive legislation (Htun et al., 2020). In other, more extreme cases, not even an effective reflection in the organization of the States is observed, as in the case of Brazil, which is still one of the worst countries in the world for recording gender violence (Roichman, 2020).

Exemplifying this reality, the Maria da Penha Law in 2006 established the National Data System on Violence against Women. Only in October 2021, fifteen years later, was the PNAINFO - National Policy of Data and Information related to Violence against Women - determined by law (Lei 14.232/2021, 2021).

Online violence stemming from technological developments has had the Internet as the main amplifier for violence against women (Zhong et al., 2020), signifying for this group a modernization by technology of the old means of perpetrating violence (Martinez-Pecino et al.,2019). The harms associated with online violence are considered a continuum of the offline 
violence suffered by the female population (Henry et al.,2015, p. 2). It is in this sense that Codin Rights and Internetlab (2017) in a report of Brazil's contribution to the UN Special Rapporteur on violence against women points out that the separation between offline and online is not recommendable in the analysis of gender violence issues.

One of the most common forms of violence against women is intimate partner violence, and they are the main victims of this form of aggression (Garcia et al., 2018). It is characterized by a pattern of behavior of the aggressor that involves from physical, violent, psychological and sexual abuse, to financial abuse (White et al., 2015). In the cyber environment, this form of violence involves using digital media to harass, pressure, threaten, coerce, or monitor (Reed et al., 2018).

When it comes to the development of legislation on violence against women on the Internet, the difficulties inherent to the profound slowness of digital law are reproduced (Jesus et al.,2016). The pace of technological evolution exceeds the adequacy capacity of legal development (Chisala-tempelhoff et al., 2016), a phenomenon that results in the absence of rules that actually protect citizens from inappropriate behavior in the cyber environment (Jesus et al., 2016).

Skinner et al. (2021) explains that gender violence is related to all forms of violence against women, so it is inferred that online violence against this group is included in the scope of gender violence. Online gender violence, although it usually coexists with traditional forms of violence, is characterized by: intensity; relational and psychological repercussions; differences in protection and justice issues; and also peculiarities of electronic evidence. Such elements express the need for a specific approach to studies on this phenomenon (Instituto Andaluz de Administración Pública, 2017, p. 31). Consider as an example sexual violence, traditionally conceptualized as any unwanted behavior, physical or non-physical, including "unwanted touching, sexual harassment, intimidation, forced sexual activity, sexual assault and rape, other physical violence, and threats to life." For Zhong et al. (2020), the definition does not adequately reflect cases of online sexual violence.

The abundance of different terms used in the study of online violence is the key challenge for researchers and policymakers. They are, among others: electronic agression, electronic harassment, online harassment, technology-based coercive behavior, online victimization, cybervictimization (Powell et al., 2019). This context has led to the development of the concept of "Technology-Facilitated Sexual Violence" (TFSV), defined as the range of behaviors in which information and communication technologies are used to facilitate virtual sexual harm (Henry \& Powell, 2018). Sexual Violence Facilitated by Technology unifies terminologies and classifies online violence into four dimensions: digital sexual harassment, image-based sexual abuse (IBSA), sexual agression and/or coercion, and gender and/or sexuality based harassment (Powell et al., 2019).

The intensity of violence against women on the Internet, as well as the fact that the female population is one of the groups most victimized by cybercrimes (Borrajo et al., 2015) are the rationale for the present study. The framing as gender violence was also a relevant issue for the analysis. The need for action by civil society and governments to address the issue, as well as the gaps in current empirical research regarding gender patterns in online sexual victimization identified by Powell and Henry (2019) finally grounded this integrative review. This study aimed to investigate the forms of violence against women on the internet in the scientific literature from 2016 to July 2021.

\section{Methodology}

In this study, the integrative literature review methodology was used, which enables a summary of what is known about a topic in a critical analysis that turns its attention to future research needs (Toronto et al., 2020). Well-formulated integrative reviews present the state of the science, contributing to theory development and containing five steps: problem formulation, literature search, evaluation, data analysis, and presentation (Whitemore et al., 2005).

In the first stage the guiding question of the research was defined, that is, the problem was formulated: What is the scientific production about the forms of violence against women on the Internet?".

In the second stage of the literature search, studies were searched for in the SciVerse Scopus (Scopus), Medical 
Literature Analysis and Retrieval System Online (PubMed) and Scientific Electronic Library Online (SciELO) databases, with descriptors defined from the incidence of a first selection made with the terms "Violence", "Internet", "Woman". Figure 1 shows the word cloud with the terms of greatest incidence and relevance in the articles searched.

Figure 1 - Word cloud (large incidence and relevance).

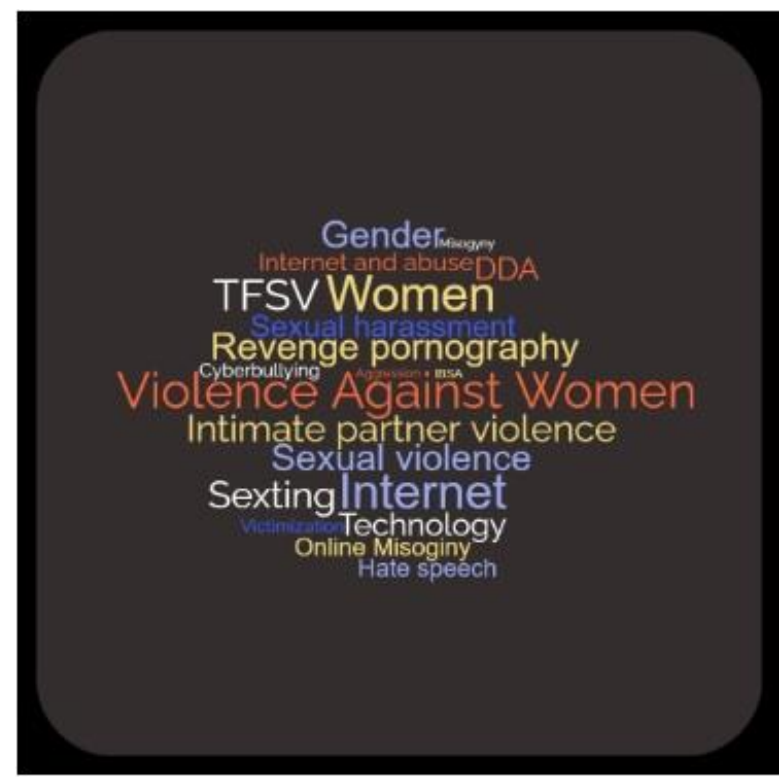

Source: Authors (2021).

The search strategy is detailed in Figure 2. The inclusion criteria were : (a) publication in the time frame from January 2016 to July 2021; (b) articles indexed by descriptors that are part of the MeSH (Medical Subject Headings) and DeCS (Health Sciences Descriptors) systems: "Violence", "Internet", "Women", "Gender", "Sexual Violence", "Sexual Harassment", "Intimate Partner Violence" and "Internet and Abuse" in the associations "Internet / Women / Violence", "Gender / Violence / Internet", "Sexual Violence / Women / Internet", "Sexual Harassment / Women / Internet", "Intimate Partner Violence / Women / Internet", all with AND connector; or articles indexed by the term "Internet and Abuse"; (c) articles answering the guiding question. The term "Internet and Abuse" was selected because it was among the most used in the search for the first association of descriptors cited in item a. 
Figure 2 - Search strategy according to data base/portal.

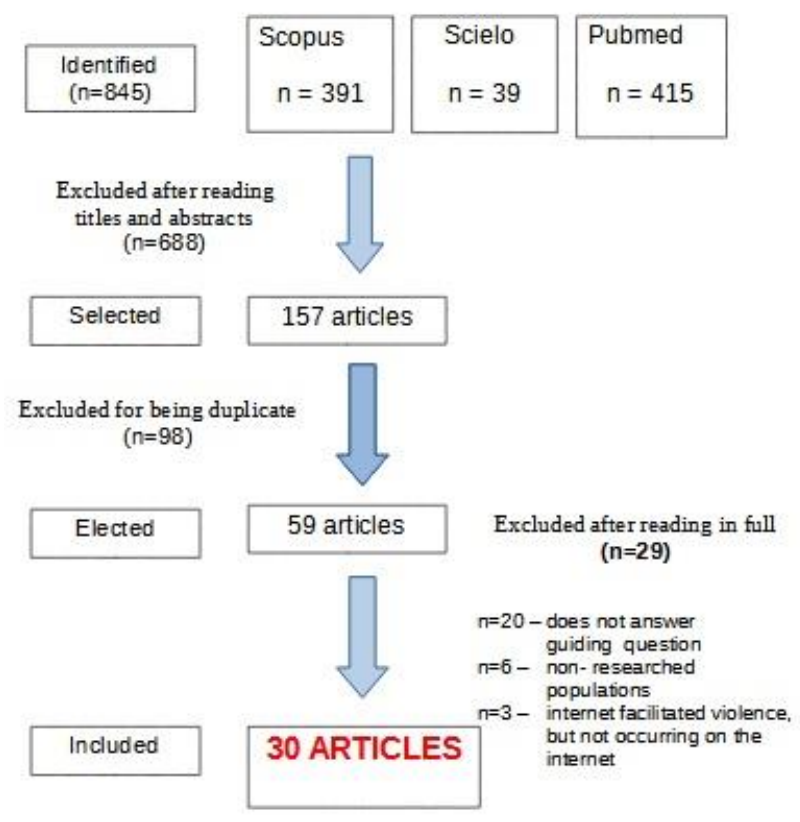

Source: Authors (2021).

Exclusion criteria were: (a) literature contained in books, book chapters, editorials, errata, notes, letters, and review articles; (b) duplicate articles.

The search identified 845 articles. The titles were read, and, in doubtful cases, the abstracts were read, excluding the articles that were not in the focus of the study $(n=688)$ or were duplicated $(n=98)$, leaving 59 articles eligible for a full reading. After reading these articles, in addition to those that did not answer the guiding question, those that dealt with: specific populations (children, sex workers or pornography in the cinema or internet, and victim-aggressive); violence facilitated by the internet, but not occurring in the virtual environment itself, such as rape facilitated by the internet were excluded. This left 30 articles for further analysis.

The third step defined by Whitemore and Knafl (2005) as data evaluation was contemplated in the literature search step, by defining the inclusion and exclusion criteria.

The fourth stage, data analysis, was carried out based on the concept of dimensions of technology-facilitated sexual violence (TFSV), proposed by Powell and Henry (2019). The authors address the existence of four dimensions of TFSV, which we detail in Table 1, with the associated categories of violence. 
Table 1 - Dimensions TFSV and Associate Categories

\begin{tabular}{|c|c|c|}
\hline $\begin{array}{c}\text { Dimension 1 } \\
\text { Digital sexual harassment }\end{array}$ & Digital sexual harassment & $\begin{array}{l}\text { Unwanted sexual behavior conducted through electronic means } \\
\text { such as e-mail, voice/video calls, text/image messages, and } \\
\text { postings on social networks, among others. }\end{array}$ \\
\hline $\begin{array}{c}\text { Dimension 2 } \\
\text { Image-based sexual abuse } \\
\text { (IBSA) } \\
\text { Non-consensual behaviors of } \\
\text { creating, obtaining, } \\
\text { distributing, sharing nude } \\
\text { and/or sexual images. }\end{array}$ & Revenge pornography & $\begin{array}{l}\text { Creating, distributing, or threatening to distribute intimate or } \\
\text { sexually explicit images of another person without his or her } \\
\text { consent }\end{array}$ \\
\hline $\begin{array}{l}\text { Dimension } 3 \\
\text { Sexual Agression and/or } \\
\text { Coercion }\end{array}$ & $\begin{array}{c}\text { Sextorsion } \\
\begin{array}{c}\text { Online distribution of assault } \\
\text { images }\end{array} \\
\text { Use of digital technologies to } \\
\text { perpetrate a physical sex crime, } \\
\text { through dating websites or apps }\end{array}$ & $\begin{array}{l}\text { Non-physical form of coercion by which the perpetrator seeks } \\
\text { sexual cooperation through illicit means such as blackmail, } \\
\text { bribery, or threats, and may involve demanding the disclosure of } \\
\text { intimate images or information } \\
\text { Capture and/or distribution of images of aggression by } \\
\text { technology, with the aim of damaging the violation of female } \\
\text { autonomy through humiliation, intimidation or harassment } \\
\text { (Not addressed) }\end{array}$ \\
\hline $\begin{array}{c}\text { Dimension } 4 \\
\text { Gender and/or sexuality } \\
\text { based harassment } \\
\text { Unwelcome verbal or visual } \\
\text { communication related to a } \\
\text { person's real or perceived } \\
\text { gender identity or sexuality. }\end{array}$ & $\begin{array}{l}\text { Online misogyny } \\
\text { Gender-based hate speech }\end{array}$ & $\begin{array}{l}\text { Online abuse aimed at silencing and censoring women } \\
\text { Discurso ou conduta ofensiva que pode incitar ao ódio ou } \\
\text { desprezo com base na sexualidade ou no gênero }\end{array}$ \\
\hline
\end{tabular}

Source: Authors (2021).

Finally, in the fifth stage, of presentation, there was the extraction of information and categorization of the selected studies, which were organized in Table 2, containing the following variables: Author, Year/country of publication, Place of study, TFSV dimension, Category of violence, Method, Objective, Main results and main conclusions.

\section{Results}

A total of 30 articles were identified, containing nine categories of violence against women on the Internet: digital dating abuse, revenge porn, sexting, online misogyny, digital sexual harassment, gender-based hate speech, cyberbullying, sextortion, and online distribution of images of aggression. The results are described in Table 2, grouped by category and method. Presented in the table are first the categories most addressed in the sample, with digital dating abuse being the most addressed (ten articles) and sextortion and online distribution of images of aggression the least addressed (one article). Within each category first the quantitative gender comparative studies are presented, and then the others (quantitative non-gender comparative studies and qualitative studies).

Although digital dating abuse was the most covered category, the most researched TFSV Dimension was Image-based sexual abuse (sexting and revenge porn), with a total of 13 studies collected.

Of the total number of studies analyzed, 15 brought quantitative comparisons of victimization between males and females; 13 identified prevalence of victimization and greater negative impacts for women than for men. Of the remainder of this subset, a single article that dealt cyberbullying and digital dating abuse observed no statistically significant gender differences. And a third that addressed only cyberbullying identified greater victimization for men. Thus, cyberbullying was 
the only category that did not show clear results of greater online victimization for women, in a small sample of 3 studies.

All of the other 15 articles (quantitative not gender comparative or qualitative) presented results that ratify the online victimization suffered by women in the cyber environment on a large scale in the other various ways identified.

The locations where the largest number of studies were conducted were: Europe (10), Latin America (6), United States (6). Four studies used internet data without geographic determination. Of the studies, only two focused on aspects of national legislation on the identified categories of online violence against women and one study addressed police knowledge of the associated legislation and level of training received.

Table 2 - Characterization and main results - integrative review violence against women on the internet

\begin{tabular}{|c|c|c|c|c|c|c|}
\hline Author & $\begin{array}{l}\text { Year/ Country } \\
\text { of Publication/ } \\
\text { Study Location }\end{array}$ & $\begin{array}{l}\text { Dimension } \\
\text { TFSV }\end{array}$ & $\begin{array}{l}\text { Violence } \\
\text { category }\end{array}$ & Method & Objective & $\begin{array}{l}\text { Main results and } \\
\text { conclusions }\end{array}$ \\
\hline $\begin{array}{l}\text { Rodríguez- } \\
\text { Castro et al. }\end{array}$ & $\begin{array}{l}2021 \\
\text { Sweden } \\
\text { Spain }\end{array}$ & $\begin{array}{l}\text { Image-based } \\
\text { sexual abuse }\end{array}$ & $\begin{array}{c}\text { Digital dating } \\
\text { abuse (DDA) } \\
\text { Sexting }\end{array}$ & $\begin{array}{l}\text { Cross-Sectional } \\
\text { Study } \\
\text { (gender } \\
\text { comparison) }\end{array}$ & $\begin{array}{l}\text { To analyze the } \\
\text { relationship between } \\
\text { cyberstalking by intimate } \\
\text { partner and gender, age, } \\
\text { sexting behaviors, } \\
\text { pornography consumption, } \\
\text { and ambivalent sexism }\end{array}$ & $\begin{array}{l}\text { Boys practice more sexting } \\
\text { and have more hostile } \\
\text { sexist attitudes than girls. } \\
\text { Hostile sexism is a } \\
\text { predictor of digital dating } \\
\text { abuse. }\end{array}$ \\
\hline Cava et al. & $\begin{array}{l}2020 \\
\text { Spain } \\
\text { Spain }\end{array}$ & - & $\begin{array}{l}\text { Digital dating } \\
\text { abuse (DDA) }\end{array}$ & $\begin{array}{l}\text { Cross-Sectional } \\
\text { Study } \\
\text { (gender } \\
\text { comparison) }\end{array}$ & $\begin{array}{l}\text { Expand knowledge about } \\
\text { variables related to cyber } \\
\text { control and cyber } \\
\text { aggression victimization } \\
\text { in adolescent boys and } \\
\text { girls }\end{array}$ & $\begin{array}{l}\text { There is more victimization } \\
\text { by cyber control for girls. }\end{array}$ \\
\hline $\begin{array}{l}\text { Martinez- } \\
\text { Pecino } \\
\text { \& Durán }\end{array}$ & $\begin{array}{l}2019 \\
\text { USA } \\
\text { Spain }\end{array}$ & - & $\begin{array}{l}\text { Digital dating } \\
\text { abuse (DDA) } \\
\text { Cyberbullying }\end{array}$ & $\begin{array}{l}\text { Cross-Sectional } \\
\text { Study } \\
\text { (gender } \\
\text { comparison) }\end{array}$ & $\begin{array}{l}\text { Determine whether } \\
\text { variables such as sexism } \\
\text { that previous research has } \\
\text { found to be related to } \\
\text { traditional violence } \\
\text { against women also } \\
\text { presage the emergence of } \\
\text { cyberbullying in dating } \\
\text { relationships. }\end{array}$ & $\begin{array}{l}\text { Men cyberbully their } \\
\text { partners more than women. }\end{array}$ \\
\hline $\begin{array}{c}\text { Cárdenas et } \\
\text { al. }\end{array}$ & $\begin{array}{l}2018 \\
\text { Colômbia } \\
\text { Mexico }\end{array}$ & - & $\begin{array}{l}\text { Digital dating } \\
\text { abuse (DDA) } \\
\text { Cyberbullying }\end{array}$ & $\begin{array}{l}\text { Cross-Sectional } \\
\text { Study } \\
\text { (gender } \\
\text { comparison) }\end{array}$ & $\begin{array}{c}\text { To analyze gender } \\
\text { differences in problematic } \\
\text { Internet use, cyberbullying } \\
\text { and cyberbullying } \\
\text { violence, as well as the } \\
\text { possible relationship } \\
\text { between these variables }\end{array}$ & $\begin{array}{l}\text { Few statistically significant } \\
\text { differences in gender } \\
\text { across most indicators, } \\
\text { including cyberbullying }\end{array}$ \\
\hline Reed et al. & $\begin{array}{l}2018 \\
\text { USA } \\
\text { USA }\end{array}$ & - & $\begin{array}{l}\text { Digital dating } \\
\text { abuse (DDA) }\end{array}$ & \begin{tabular}{|l|} 
Cross-Sectional \\
Self-Report \\
Study \\
(gender \\
comparison) \\
\end{tabular} & $\begin{array}{l}\text { Exploring dating beliefs } \\
\text { and gender stereotypes } \\
\text { (SGDBs) as predictors of } \\
\text { perpetration of digital } \\
\text { dating abuse }\end{array}$ & $\begin{array}{c}\text { Boys exert power over girls } \\
\text { in heterosexual } \\
\text { relationships. }\end{array}$ \\
\hline Reed et al. & $\begin{array}{l}2017 \\
\text { England } \\
\text { USA }\end{array}$ & - & $\begin{array}{l}\text { Digital dating } \\
\text { abuse (DDA) }\end{array}$ & \begin{tabular}{|l|} 
Cross-Sectional \\
Self-Report \\
Study \\
(gender \\
comparison)
\end{tabular} & $\begin{array}{l}\text { Examine the experience } \\
\text { and consequences of DDA } \\
\text { victimization in high } \\
\text { school dating } \\
\text { relationships. }\end{array}$ & $\begin{array}{l}\text { Girls experience more } \\
\text { digital sexual coercion than } \\
\text { boys and express more } \\
\text { negative emotional } \\
\text { responses, more severe } \\
\text { emotional consequences } \\
\text { and behavioral impacts } \\
\text { offline, especially if } \\
\text { victims of digital sexual } \\
\text { coercion }\end{array}$ \\
\hline
\end{tabular}




\begin{tabular}{|c|c|c|c|c|c|c|}
\hline Reed et al. & $\begin{array}{l}2016 \\
\text { USA } \\
\text { USA }\end{array}$ & $\begin{array}{l}\text { Image-based } \\
\text { sexual abuse }\end{array}$ & $\begin{array}{l}\text { Digital dating } \\
\text { abuse (DDA) } \\
\text { Sexting }\end{array}$ & $\begin{array}{l}\text { Cross-Sectional } \\
\text { Study } \\
\text { (gender } \\
\text { comparison) }\end{array}$ & $\begin{array}{c}\text { Examining the } \\
\text { victimization and } \\
\text { perpetration of potentially } \\
\text { harmful digital dating } \\
\text { abuse behaviors among } \\
\text { college students }\end{array}$ & $\begin{array}{l}\text { Girls and women have } \\
\text { more negative reactions } \\
\text { and may suffer more } \\
\text { damage from DDA than } \\
\text { boys and men. }\end{array}$ \\
\hline $\begin{array}{c}\text { Hellevik } \\
\& \text { Øverlien }\end{array}$ & $\begin{array}{l}2016 \\
\text { England } \\
\text { Norway }\end{array}$ & - & $\begin{array}{l}\text { Digital dating } \\
\text { abuse (DDA) }\end{array}$ & $\begin{array}{l}\text { Cross-Sectional } \\
\text { Study } \\
\text { (gender } \\
\text { comparison) }\end{array}$ & $\begin{array}{c}\text { Investigate factors of } \\
\text { victimization by intimate } \\
\text { partner violence in } \\
\text { adolescence, and aspects } \\
\text { of digital media use and } \\
\text { impacts on boys and girls. }\end{array}$ & $\begin{array}{l}\text { Being female is one of the } \\
\text { significant factors of } \\
\text { intimate partner } \\
\text { victimization in } \\
\text { adolescence, with girls } \\
\text { being at higher risk than } \\
\text { boys of being victims of } \\
\text { digital and sexual violence, } \\
\text { as well as being more } \\
\text { negatively impacted by this } \\
\text { victimization }\end{array}$ \\
\hline $\begin{array}{l}\text { Gracia- } \\
\text { Leiva et al. }\end{array}$ & $\begin{array}{c}2020 \\
\text { Sweden } \\
\text { Chile }\end{array}$ & - & $\begin{array}{l}\text { Digital dating } \\
\text { abuse (DDA) }\end{array}$ & $\begin{array}{l}\text { Cross-Sectional } \\
\text { Study }\end{array}$ & $\begin{array}{l}\text { To examine the } \\
\text { relationship between } \\
\text { young women's dating } \\
\text { violence victimization (off } \\
\text { and online) with suicide } \\
\text { risk (SR) and parental and } \\
\text { peer support }\end{array}$ & $\begin{array}{l}68.8 \% \text { of women in the } \\
\text { sample experienced online } \\
\text { dating violence; } 56.8 \% \\
\text { online and offline. Over } \\
50 \% \text { experienced coercion } \\
\text { and } 1 / 3 \text { direct assault. } \\
\text { Higher risk of suicidal } \\
\text { ideation and attempt for } \\
\text { victims of the online form } \\
\text { than for non-victims. } \\
\text { Violence triples risk of } \\
\text { suicidal ideation }\end{array}$ \\
\hline $\begin{array}{c}\text { Stonard et } \\
\text { al. }\end{array}$ & $\begin{array}{c}2017 \\
\text { USA } \\
\text { Uni. Kingdom }\end{array}$ & - & $\begin{array}{l}\text { Digital dating } \\
\text { abuse (DDA) }\end{array}$ & $\begin{array}{l}\text { Qualitative } \\
\text { study }\end{array}$ & $\begin{array}{l}\text { To explore the role and } \\
\text { impact of technology on } \\
\text { romantic relationships, } \\
\text { abuse, and dating violence } \\
\text { among adolescents }\end{array}$ & $\begin{array}{l}\text { Adolescents' perceptions } \\
\text { and experiences of } \\
\text { technology-related, } \\
\text { romantic relationships and } \\
\text { their abusive behaviors } \\
\text { vary by gender. Women are } \\
\text { more likely to experience a } \\
\text { greater emotional impact. }\end{array}$ \\
\hline $\begin{array}{l}\text { Powell } \\
\& \text { Henry }\end{array}$ & $\begin{array}{c}2019 \\
\text { USA Australia }\end{array}$ & $\begin{array}{c}\text { Addresses the } \\
4 \text { dimensions }\end{array}$ & $\begin{array}{l}\text { Digital Sexual } \\
\text { Harassment } \\
\text { Gender-based } \\
\text { hate speech } \\
\text { Online } \\
\text { distribution of } \\
\text { images of the } \\
\text { assault } \\
\text { Sexting } \\
\text { Sextortion } \\
\text { Revenge porn }\end{array}$ & $\begin{array}{l}\text { Cross-Sectional } \\
\text { Study } \\
\text { (gender } \\
\text { comparison) }\end{array}$ & $\begin{array}{l}\text { To explore the nature of } \\
\text { the prevalence and } \\
\text { impacts of technology- } \\
\text { facilitated sexual violence } \\
\text { victimization among } \\
\text { adults in Australia }\end{array}$ & $\begin{array}{c}\text { Women experience } \\
\text { significantly more sexual } \\
\text { harassment online, with } \\
\text { greater negative impacts. } \\
\text { TFSV can be gendered } \\
\text { because the nature and } \\
\text { impacts of experiences } \\
\text { differ in specific ways, as a } \\
\text { reflection of broader } \\
\text { patterns. }\end{array}$ \\
\hline $\begin{array}{c}\text { Bond } \\
\& \text { Tyrrell }\end{array}$ & EUA $\stackrel{2021}{\text { Inglaterra }}$ & $\begin{array}{l}\text { Image-based } \\
\text { sexual abuse }\end{array}$ & Revenge porn & $\begin{array}{l}\text { Cross-Sectional } \\
\text { Study }\end{array}$ & $\begin{array}{l}\text { Investigate police } \\
\text { knowledge of revenge } \\
\text { porn legislation, their } \\
\text { confidence in responding } \\
\text { to cases, and level of } \\
\text { training received }\end{array}$ & $\begin{array}{c}\text { Revenge porn } \\
\text { disproportionately affects } \\
\text { women. Limited police } \\
\text { understanding of } \\
\text { legislation, which leads to } \\
\text { few criminal convictions }\end{array}$ \\
\hline Gius & $\begin{array}{l}2021 \\
\text { Uni. Kingdom } \\
\text { Italy }\end{array}$ & $\begin{array}{l}\text { Image-based } \\
\text { sexual abuse } \\
\text { Harassment } \\
\text { based on } \\
\text { gender and/or } \\
\text { sexuality }\end{array}$ & $\begin{array}{c}\text { Revenge porn } \\
\text { Online } \\
\text { misogyny }\end{array}$ & Case study & $\begin{array}{l}\text { Examine the sociocultural } \\
\text { implications of non- } \\
\text { consensual pornography } \\
\text { practices in contemporary } \\
\text { Italian public debate }\end{array}$ & $\begin{array}{l}\text { The price paid by women } \\
\text { whose private videos or } \\
\text { photos are made public } \\
\text { without their consent is } \\
\text { proportional to the social } \\
\text { guilt that women's } \\
\text { sexuality catalyzes when it } \\
\text { deviates from socially } \\
\text { accepted norms for their } \\
\text { gender. }\end{array}$ \\
\hline
\end{tabular}




\begin{tabular}{|c|c|c|c|c|c|c|}
\hline $\begin{array}{l}\text { Henry } \\
\text { \& Flynn }\end{array}$ & $\begin{array}{c}2019 \\
\text { USA } \\
\text { Internet }\end{array}$ & $\begin{array}{l}\text { Image-based } \\
\text { sexual abuse }\end{array}$ & Revenge porn & $\begin{array}{l}\text { Digital } \\
\text { Ethnographic } \\
\text { Study }\end{array}$ & $\begin{array}{l}\text { Investigating the nature } \\
\text { and scope of image-based } \\
\text { sexual abuse (IBSA) on } 77 \\
\text { high-volume online sites. }\end{array}$ & $\begin{array}{l}\text { IBSA's non-consensual } \\
\text { distribution transcends the } \\
\text { "ex-lover's" revenge } \\
\text { narrative. }\end{array}$ \\
\hline Ruiz et al. & $\begin{array}{l}2019 \\
\text { Spain } \\
\text { Brazil }\end{array}$ & $\begin{array}{l}\text { Image-based } \\
\text { sexual abuse }\end{array}$ & Revenge porn & $\begin{array}{l}\text { Functional } \\
\text { Study of } \\
\text { Comparative } \\
\text { Law }\end{array}$ & $\begin{array}{l}\text { Investigate the treatment } \\
\text { of the dissemination of } \\
\text { non-consensual intimate } \\
\text { images (revenge porn) in } \\
11 \text { countries from the } \\
\text { point of view of Internet } \\
\text { Service Provider (ISP) } \\
\text { policy and state regulation }\end{array}$ & $\begin{array}{l}\text { In } 11 \text { countries, the debate } \\
\text { about the role of Internet } \\
\text { providers in violations } \\
\text { against women is at a } \\
\text { turning point. }\end{array}$ \\
\hline $\begin{array}{c}\text { Sambasivan } \\
\text { et al. }\end{array}$ & $\begin{array}{l}2019 \\
\text { Uni. Kingdom } \\
\text { Asia }\end{array}$ & $\begin{array}{l}\text { Image-based } \\
\text { sexual abuse }\end{array}$ & Revenge porn & $\begin{array}{l}\text { Qualitative } \\
\text { study }\end{array}$ & $\begin{array}{l}\text { Examine online abuse in } \\
\text { South Asian women, its } \\
\text { consequences, coping } \\
\text { practices through } \\
\text { technology. }\end{array}$ & $\begin{array}{l}\text { Women face regular online } \\
\text { abuse ( } 72 \% \text { of the sample } \\
\text { experienced it only once), } \\
\text { with severe consequences. } \\
\text { Younger, rural, low- } \\
\text { income, and minority } \\
\text { women reported more } \\
\text { abuse. Social media offers } \\
\text { new spaces and empowers } \\
\text { patriarchal control. }\end{array}$ \\
\hline $\begin{array}{l}\text { Chisala- } \\
\text { Tempelhoff } \\
\text { \& Kirya }\end{array}$ & $\begin{array}{l}2016 \\
\text { Uni. Kingdom } \\
\text { Africa }\end{array}$ & $\begin{array}{l}\text { Image-based } \\
\text { sexual abuse }\end{array}$ & Revenge porn & Case study & $\begin{array}{l}\text { To explore the legal } \\
\text { responses to revenge } \\
\text { pornography in a non- } \\
\text { Western context and the } \\
\text { (in) adequacy of legal } \\
\text { regimes to deal with this } \\
\text { new form of gender-based } \\
\text { violence }\end{array}$ & $\begin{array}{l}\text { Conduct not recognized as } \\
\text { a crime. Legal structures do } \\
\text { not protect victims or } \\
\text { prevent crime, without } \\
\text { meeting international } \\
\text { obligations of women's } \\
\text { rights and constitution }\end{array}$ \\
\hline $\begin{array}{l}\text { Marcotte et } \\
\text { al. }\end{array}$ & $\begin{array}{l}2020 \\
\text { USA } \\
\text { USA }\end{array}$ & $\begin{array}{l}\text { Image-based } \\
\text { sexual abuse }\end{array}$ & Sexting & $\begin{array}{l}\text { Cross-Sectional } \\
\text { Study } \\
\text { (gender } \\
\text { comparison) }\end{array}$ & $\begin{array}{l}\text { Examine positive and } \\
\text { negative responses to } \\
\text { receiving an unsolicited } \\
\text { image of a male genital } \\
\text { organ, considering } \\
\text { contexts of gender } \\
\text { hegemony, sexual } \\
\text { harassment, and sexism. }\end{array}$ & $\begin{array}{c}90.7 \% \text { of women received } \\
\text { an unsolicited image of a } \\
\text { male genital organ, with } \\
\text { negative reactions } \\
\text { prevailing }(69 \%)\end{array}$ \\
\hline Ross et al. & $\begin{array}{l}2019 \\
\text { USA } \\
\text { USA }\end{array}$ & $\begin{array}{l}\text { Image-based } \\
\text { sexual abuse }\end{array}$ & Sexting & $\begin{array}{l}\text { Cross-Sectional } \\
\text { Study } \\
\text { (gender } \\
\text { comparison) }\end{array}$ & $\begin{array}{c}\text { Determine whether } \\
\text { sexting coercion as a } \\
\text { component of intimate } \\
\text { partner abuse among } \\
\text { young adults appears } \\
\text { along with other forms of } \\
\text { aggression as a cumulative } \\
\text { risk factor for } \\
\text { psychological, sexual. }\end{array}$ & $\begin{array}{l}\text { Coercive sexting is more } \\
\text { frequent among women, } \\
\text { with higher rates than } \\
\text { sexual coercion and } \\
\text { unwanted sexual } \\
\text { intercourse }\end{array}$ \\
\hline Stanley et al. & $\begin{array}{c}2018 \\
\text { USA } \\
\text { Europe }\end{array}$ & $\begin{array}{l}\text { Image-based } \\
\text { sexual abuse }\end{array}$ & Sexting & $\begin{array}{l}\text { Cross-Sectional } \\
\text { Study } \\
\text { (gender } \\
\text { comparison) }\end{array}$ & $\begin{array}{l}\text { Investigate whether } \\
\text { regular viewing of online } \\
\text { pornography represents a } \\
\text { risk factor for perpetuating } \\
\text { sexual coercion and abuse } \\
\text { in young people's intimate } \\
\text { relationships, and whether } \\
\text { it is associated with } \\
\text { sexting }\end{array}$ & $\begin{array}{l}\text { Clear association between } \\
\text { regular viewing of online } \\
\text { pornography with } \\
\text { perpetration of sexual } \\
\text { coercion and abuse by } \\
\text { boys. }\end{array}$ \\
\hline $\begin{array}{l}\text { Rubio- } \\
\text { Laborda et } \\
\text { al. }\end{array}$ & $\begin{array}{l}2021 \\
\text { Spain } \\
\text { Spain }\end{array}$ & $\begin{array}{l}\text { Image-based } \\
\text { sexual abuse }\end{array}$ & Sexting & $\begin{array}{l}\text { Cross-Sectional } \\
\text { Study } \\
\text { Descriptive } \\
\text { (gender } \\
\text { comparison) }\end{array}$ & $\begin{array}{c}\text { Identify characteristics of } \\
\text { sexist violence in different } \\
\text { technological generations } \\
\text { (Millennials and } \\
\text { Generation X). }\end{array}$ & $\begin{array}{l}\text { In an environment of } \\
\text { violent relationships in } \\
\text { virtual environments, } \\
\text { women suffer sexual } \\
\text { pressure and are subjected } \\
\text { through fear and sexual } \\
\text { coercion by men }\end{array}$ \\
\hline
\end{tabular}




\begin{tabular}{|c|c|c|c|c|c|c|}
\hline Blake et al. & $\begin{array}{l}2021 \\
\text { USA } \\
\text { USA }\end{array}$ & $\begin{array}{l}\text { Harassment } \\
\text { based on } \\
\text { gender and/or } \\
\text { sexuality }\end{array}$ & $\begin{array}{l}\text { Online } \\
\text { misogyny }\end{array}$ & $\begin{array}{c}\text { Cross-Sectional } \\
\text { Study }\end{array}$ & $\begin{array}{l}\text { Examine the relationship } \\
\text { between the frequency of } \\
\text { misogynistic attitudes } \\
\text { expressed on Twitter and } \\
\text { reported incidents of } \\
\text { domestic and family } \\
\text { violence }\end{array}$ & $\begin{array}{l}\text { Misogynistic posts on } \\
\text { Twitter were related to the } \\
\text { incidence of domestic and } \\
\text { family violence. } \\
\text { Geolocated online } \\
\text { misogyny co-occurs with } \\
\text { this form of violence }\end{array}$ \\
\hline $\begin{array}{l}\text { Garcia-Díaz } \\
\text { et al. }\end{array}$ & $\begin{array}{l}2021 \\
\text { Spain } \\
\text { Internet }\end{array}$ & $\begin{array}{l}\text { Harassment } \\
\text { based on } \\
\text { gender and/or } \\
\quad \text { sexuality }\end{array}$ & $\begin{array}{l}\text { Online } \\
\text { misogyny } \\
\text { Gender based } \\
\text { hate speech }\end{array}$ & $\begin{array}{c}\text { Cross-Sectional } \\
\text { Study }\end{array}$ & $\begin{array}{l}\text { Understand the main } \\
\text { linguistic phenomena that } \\
\text { contribute to the } \\
\text { identification of misogyny } \\
\text { on twitter in the Spanish } \\
\text { language }\end{array}$ & $\begin{array}{l}\text { Misogyny shares } \\
\text { characteristics of different } \\
\text { cultural backgrounds on } \\
\text { twitter }\end{array}$ \\
\hline $\begin{array}{c}\text { Soto } \\
\text { \& Sanchez }\end{array}$ & $\begin{array}{l}2019 \\
\text { Spain } \\
\text { Chile }\end{array}$ & $\begin{array}{l}\text { Harassment } \\
\text { based on } \\
\text { gender and/or } \\
\text { sexuality }\end{array}$ & $\begin{array}{l}\text { Online } \\
\text { misogyny }\end{array}$ & $\begin{array}{c}\text { Cross-Sectional } \\
\text { Study }\end{array}$ & $\begin{array}{l}\text { Exploring gender-based } \\
\text { violence on the Internet } \\
\text { affecting feminists and } \\
\text { other human rights } \\
\text { activists }\end{array}$ & $\begin{array}{c}73.6 \% \text { of female activists } \\
\text { were victims of internet } \\
\text { violence, The police and } \\
\text { judiciary did not } \\
\text { demonstrate preparedness } \\
\text { to face events }\end{array}$ \\
\hline Andreasen & $\begin{array}{l}2020 \\
\text { Uni. Kingdom } \\
\text { Internet }\end{array}$ & $\begin{array}{l}\text { Harassment } \\
\text { based on } \\
\text { gender and/or } \\
\quad \text { sexuality }\end{array}$ & $\begin{array}{l}\text { Online } \\
\text { misogyny }\end{array}$ & Case study & $\begin{array}{c}\text { Explore how women } \\
\text { victims of sexual violence } \\
\text { are portrayed in Internet } \\
\text { memes }\end{array}$ & $\begin{array}{l}\text { Sexual violence on the } \\
\text { internet is mischaracterized } \\
\text { negatively for women, who } \\
\text { are blamed }\end{array}$ \\
\hline $\begin{array}{l}\text { Remón \& } \\
\text { Medina- } \\
\text { Bravo. }\end{array}$ & $\begin{array}{l}2018 \\
\text { The Netherlands } \\
\text { Internet }\end{array}$ & $\begin{array}{l}\text { Harassment } \\
\text { based on } \\
\text { gender and/or } \\
\text { sexuality }\end{array}$ & $\begin{array}{l}\text { Online } \\
\text { misogyny }\end{array}$ & Case study & $\begin{array}{l}\text { Explore the reach and } \\
\text { strategies of anti-feminist } \\
\text { cyberviolence present in } \\
\text { the Comments section of } \\
\text { YouTube }\end{array}$ & $\begin{array}{l}56.2 \% \text { of comments had } \\
\text { anti-feminist violence } \\
\text { content, coercing to } \\
\text { silencing. }\end{array}$ \\
\hline Soto & $\begin{array}{l}2018 \\
\text { Spain } \\
\text { Chile }\end{array}$ & $\begin{array}{l}\text { Harassment } \\
\text { based on } \\
\text { gender and/or } \\
\quad \text { sexuality }\end{array}$ & $\begin{array}{l}\text { Online } \\
\text { misogyny } \\
\text { Gend } \\
\text { er based } \\
\text { hate } \\
\text { speech }\end{array}$ & Case study & $\begin{array}{c}\text { Analyze the readers' } \\
\text { discourse when faced with } \\
\text { two cases of police } \\
\text { violence }\end{array}$ & $\begin{array}{l}\text { Between } 25 \% \text { and } 35 \% \text { of } \\
\text { the comments evaluated } \\
\text { attacked female victims } \\
\text { with re-victimization, guilt } \\
\text { and transcendence of } \\
\text { violence to the digital } \\
\text { environment. }\end{array}$ \\
\hline $\begin{array}{c}\text { Douglass et } \\
\text { al. }\end{array}$ & $\begin{array}{l}2018 \\
\text { Australia } \\
\text { Australia }\end{array}$ & $\begin{array}{c}\text { Digital } \\
\text { Sexual } \\
\text { Harassment }\end{array}$ & $\begin{array}{c}\text { Digital Sexual } \\
\text { Harassment }\end{array}$ & $\begin{array}{l}\text { Cross-Sectional } \\
\text { Study } \\
\text { (gender } \\
\text { comparison) }\end{array}$ & $\begin{array}{l}\text { To identify the frequency } \\
\text { and correlates of in-person } \\
\text { and technology-facilitated } \\
\text { sexual harassment in a } \\
\text { sample of young } \\
\text { Australians }\end{array}$ & $\begin{array}{c}\text { Young women are among } \\
\text { groups most likely to } \\
\text { experience digital sexual } \\
\text { harassment }\end{array}$ \\
\hline Burnay et al. & $\begin{array}{c}2019 \\
\text { USA } \\
\text { Belgium }\end{array}$ & $\begin{array}{c}\text { Digital } \\
\text { Sexual } \\
\text { Harassment }\end{array}$ & $\begin{array}{c}\text { Digital Sexual } \\
\text { Harassment }\end{array}$ & $\begin{array}{l}\text { Experimental } \\
\text { Study (Quant.) }\end{array}$ & $\begin{array}{l}\text { Determine the effect of } \\
\text { video games with } \\
\text { sexualized content on } \\
\text { digital sexual harassment } \\
\text { behavior of men and } \\
\text { women }\end{array}$ & $\begin{array}{c}\text { Sexualization of female } \\
\text { characters in video games } \\
\text { may be sufficient condition } \\
\text { for online sexual } \\
\text { harassment of women. }\end{array}$ \\
\hline Cerón et al. & $\begin{array}{l}2018 \\
\text { Chile } \\
\text { Chile }\end{array}$ & - & Cyberbullying & $\begin{array}{l}\text { Exploratory } \\
\text { Descriptive } \\
\text { Study (gender } \\
\text { comparison) }\end{array}$ & $\begin{array}{l}\text { Identify and describe } \\
\text { Cyberbullying, Sexting } \\
\text { and Grooming in } \\
\text { elementary and high } \\
\text { school students in Chile } \\
\text { according to school } \\
\text { management type and } \\
\text { gender }\end{array}$ & $\begin{array}{l}\text { Women suffer less } \\
\text { cyberbullying than men. }\end{array}$ \\
\hline
\end{tabular}

Note. Articles that refer to the categories digital dating abuse and cyberbullying (not contained in the TFSV Dimensions) contain this field not filled in the table. Source: Authors (2021). 


\section{Discussion}

The studies confirmed that women are more victimized by online violence than men, with greater negative impacts. These are gender-based violence directly linked to the real (physical) world, where discriminatory social and moral relations associated with patriarchy reproduce and reinforce patterns of inequality (Silva, 2016).

In addition to "gender gaps," i.e., lower access of the female population to technologies, especially poor and rural women (Sambasivan et al., 2019), as well as, lower professional presence of women in the area of tic (Selaimen, 2013), offline aggressive tendencies of men against women are expressed in the digital environment in an exponentially multiplied way (Instituto Andaluz de Administración Pública, 2017, p. 9). This direct violence have as main factors of exacerbation the anonymity, repetition, virality, diffusion, normalization and sum of aggressors. Thus, the internet turns out to be a complementary, unique and major factor in the decision to perpetrate technology-facilitated sexual violence (Zhong et al., 2020). It is in this sense that Martinez-Pecino and Durán (2019) address the internet as modernizing the means of perpetrating violence against women.

To the detriment of this trend, gaps are evident in many jurisdictions in legislative responses to harms associated with violence against women on the internet (Henry \& Powell, 2018). Legal and regulatory responses are slow and limited by challenging aspects of the Internet (Soto et al., 2019). Even when applicable laws exist, a vacuum of judicial and police authorities are observed in dealing with events (Bond et al., 2021; Sambasivan et al., 2019; Ruiz et al., 2019). In this context, informal channels are the means of addressing digital abuse in South Asia, at the detriment of technological protections or law enforcement (Sambasivan et al., 2019)

Investigating internet service providers' governing legislation on violations against women in 11 countries, Ruiz et al. (2019) identified a lack of uniformity of targeting. The policies adopted by providers are visible, but not transparent and reliable, with no publication of content takedown data, the amount of cases resolved, and the reasons for refusal of takedown and duration of processing.

Online violence against the female population, affects young women in particular, aged between 18 and 35 years (Soto \& Sanchez, 2019). A good portion of the studies collected in this review investigated young populations in which this reality was observed (Rodríguez-Castro et al., 2021; Rubio-Laborda et al., 2021; Gracia-Levia et al., 2020). We align the considerations of this study with reflections of Bonavitta et al. (2020) in stating that technology is not only a re-inforcer of gender differences, but an amplifier of patriarchy as a strong structure of domination.

\section{Sexual Violence Facilitated by Technology - Dimensions of TFSV}

Understanding violence against women as gendered violence allows one to consider the unequal power relations between women and men created and maintained by associated stereotypes, making it possible to observe the similarities and differences in violence experienced by genders (Montesanti, 2015). Also, technology-facilitated sexual violence can be gendered, as the nature and impacts of internet assault experiences differ in specific ways as a reflection of sexist patterns (Powell et al., 2019).

Women are 27 times more likely to be victims of online abuse than men (Remón et al., 2019). Powell and Henry (2019) found expressive difference in the response of men and women to TFSV: $56.1 \%$ of women reported the experience as at least moderately upsetting. In addition, several studies identify that digital sexual harassment, TFSV Dimension 1, is a category of violence whose data always indicate higher prevalence of victimization and more negative impacts for women (Douglass et al., 2018; Powell \& Henry, 2019; Burnay et al., 2019).

Two limitations are noted in research on digital sexual harassment in general. The first is that most surveys are conducted with young people; there is also an absence of a clear definition of what digital sexual harassment is for 
respondents, which may suggest under-reporting, since victims do not always correctly label their experiences (Powell \& Henry, 2019).

digital sexual harassment has been measured by the Pew Research Center in the US, revealing that victimization rates are on the order of $25 \%$ for women, compared to $13 \%$ for men. Women between the ages of 18 and 24 experience the phenomenon at disproportionately high levels and are more likely to experience this form of harassment (Douglass et al., 2018; Powell \& Henry, 2019). Also in the online video game environment, an experimental study proved that the sexualization of female characters influenced digital sexual harassment, but only for women; it is therefore concluded that it is a sufficient condition for women to experience digital sexual harassment (Burnay et al., 2019).

Image Based Sexual Abuse (IBSA), TFSV Dimension 2, encompasses sexting and revenge pornography, categories in which women are disproportionately affected in quantity and social stigma (Bond et al., 2021; Henry et al., 2019; Ross et al., 2019).

Rubio-Laborda et al. (2021) addresses an interesting bias when they cite the contrast between the violence of public exposure associated with Dimension 2 and the traditional and hidden domestic violence that occurs in the privacy of the home, which they call the "paradox of digital violence". This is an aspect that the author believes deserves more in-depth studies, which we share.

Non-consensual sexting, the modality investigated in this review, involves sexting received but "unsolicited"; and sexting sent by coercion, or "unwanted but consented". In the case of sexting sent by coercion, these rates are higher than in sexual coercion and unwanted sexual intercourse (Ross et al., 2019) and the psychological trauma associated with sharing personal images with others, or worrying about this having occurred is also higher among women (Ross et al., 2019; RubioLaborda et al., 2021). As for unsolicited sexting received, a study by Marcotte et al. (2020) showed that $90.7 \%$ of the women in the sample had received unsolicited images of the male genital organ, and $69 \%$ had expressed a negative reaction.

Cornelius et al. (2020) points out limitations in research on sexting: the lack of association with influences of intimate partner aggression; failure to differentiate between consensual and non-consensual sexting; and over-focus on potential risk factors and associated negative consequences. Stanley et al. (2018), after researching pornography viewing habits in 4,564 young people from five European countries, suggests that sexting replaces the habit of pornography viewing. It identifies regular viewing of online pornography as clearly associated with the perpetration of sexual coercion and abuse by boys and adds that sexism and misogyny are factors that undermine the value of pornography as a tool for sexual education.

The association of porn viewing with online violence was also studied by Henry and Flynn (2019), investigating 77 IBSA bulk data sites, in which they concluded that the label of "revenge porn" undermines understanding of the phenomenon, as the non-consensual distribution occurring on these sites is more complex than the "ex-lover" revenge narrative. The lack of understanding of the phenomenon is identified by Gius (2021), for whom the category is not seen as an expression of a systemic form of violence. Often men engage in these behaviors to bond with their male peers, not just for sexual satisfaction, with key elements being the objectification and degradation of women, in order to cause maximum public shame and humiliation to the victims Henry and Flynn (2019).

Revenge porn involves behaviors such as cyber stalking (cyberstalking), identity theft, and leaks of personal content, with serious consequences such as reputational damage, mental and emotional harm, coercive and physical relationships (Sambasivan et al., 2019). Revenge pornography is the category that in this review showed the largest number of studies focused on the aspects of public safety legislation and policy. The totality of these studies identified ineffective responses to victims (Gius, 2021; Sambasivan et al., 2019; Ruiz et al., 2019; Chisala-Tempelhoff \& Kyria, 2016), and for Bond and Tyrrell (2021) there are few criminal convictions and low police officers' understanding of related legislation, as well as a lack of reliability in investigative (Bond et al.,, 2021). 
TFSV Dimension 3, ICT-facilitated sexual agression and coercion, which in our review includes sextortion and distribution of assault images, has a small empirical base, with a paucity of research with adult populations (Henry et al., 2018). We confirmed this finding, as there was identification of a single study that addressed the categories. Extensive research conducted in Australia with 2,956 people identified only a maximum of $11.1 \%$ responses on this dimension (Powell \& Henry, 2019).

In TFSV Dimension 4, abuse based on gender and sexuality, in virtual spaces such as YouTube can be used for cyber violence and hate speech against women. Different research agrees that the sarcastic, personalized, and violent language found on various social networks is primarily directed at women (Remón et al., 2019). In these environments, sexual violence is invisibilized, represented as sexy, legitimized and normalized by humor. Male sexual impulse and lack of control are portrayed as natural, with female victims being blamed (Gius, 2021). There are even records of concern about the potential damage to the perpetrators' careers (Andreasen, 2020). In social networks such as Twitter, with strong linguistic expression, Garcia-Díaz et al. (2021) concluded that online misogyny shares characteristics of different cultural backgrounds and linguistic resources.

In online misogyny and gender-based hate speech, rape culture justifies violence. They are expressed through attacks, use of insults and defamation, lack of empathy and devaluation of their sufferings, victim-blaming of physical violence, with its transcendence to the digital environment against women (Soto, 2018; Gius, 2021). When the victims are feminists, the contents of digital violence reveal coercion mechanisms for silencing, with alarming rates of $73.6 \%$ of victimized activists (Soto et al., 2019) and lack of preparation of the police and judiciary to deal with the situations. The results indicate a complexity that goes beyond mere sexual objectification (Remón et al., 2019). In a case study involving suicide, investigating revenge porn and online misogyny, Gius (2021) concludes that the consequences of the association of these categories of women's violence is catalyzed when there is deviation from socially accepted norms for their gender.

A study by Blake et al. (2021) further identified online misogyny, occurring on Twitter, as related to domestic and family violence. The research was the first to use large amounts of data (misogynistic tweets) for the period of two years, showing the prediction of incidents of this type of violence after 1 year. The study demonstrated how understanding the reach of violence on social media can help analyze and thus combat violence against women.

\section{DDA - Digital Dating Abuse and Cyberbullying}

The classification of TFSV used as an analysis parameter in this review does not include digital dating abuse (DDA). However, a significant amount of studies were identified in this research, that addresses the topic, by relating it to intimate partner violence. Ross et al. (2019) state that digital sexual violence is a new component of intimate partner poly-victimization, potentially increasing the negative effects that victims experience.

Digital dating abuse is defined as controlling, harassing, threatening, stalking, and abusing dating partners and former dating partners via technology and social media (Cava et al., 2020). Cyberbullying is aggressive online behavior that is intentional and repeated with the goal of inflicting harm (Aizenkot et al., 2019).

Young women experience online dating violence, that may continue in the real world and vice versa, (Gracia-Leiva et al., 2020), experiencing more digital sexual coercion (Reed et al., 2017). There is evidence of stronger association of this category of violence with direct assault for females between the ages of 18 and 30 (Borrajo et al., 2015). In adolescence, being female is a significant risk factor for DDA (Hellevik et al., 2016), with girls having an increased risk of sexual digital violence (Cava et al., 2020). These authors concluded that offline dating violence victimization and romantic myths are significant predictors of control and aggression victimization in the digital environment for boys and girls. However, the association of romantic myths, and gender stereotypes with the types of DDAs perpetrated differ between genders, allowing boys to exert 
power over girls. Cultural gender norms, beliefs, and inequality are key factors in the perpetration, observing a vicious cycle that feeds back gender inequalities (Reed et al., 2018).

In adolescent groups, less pernicious forms of DDA are further reported by Rodríguez-Castro et al. (2021). The study used the terminology Intimate Partner Cyberstalking (IPCS), in which we identified actions characteristic of DDA, and also investigated sexting. Results showed that boys practice more sexting and have more hostile sexist attitudes than girls, and that hostile sexism is a predictor of digital dating abuse.

Women are more likely to experience greater emotional impact in DDA (Stonard et al., 2017; Hellevik \& Øverlien (2016), including anticipated emotional reactions to sexting (Reed et al., 2016) and more severe emotional consequences and behavioral impacts offline, especially when experiencing digital sexual coercion (Reed et al., 2017).

Suicide is one of the most serious consequences of DDA. Online victims compared to non-victims have 3.5 times higher risk of suicidal ideation and suicide attempts, with direct assault as the main factor. Suffering online and offline violence increases the risk of suicidal ideation by nearly three times compared to women who do not report the experience. Support from parents and peers are key to reducing risk (Gracia-Leiva et al., 2020).

This review identified studies that addressed cyberbullying as violence against women, however presenting disparate results in a small sample found. We confirm Aizenkot and Kashy-Rosenbaum's (2019) perception of inconsistencies in the various studies on cyberbullying regarding gender. Cárdenas et al. (2018) and Cerón et al. (2018) state that men are more victimized by cyberbullying. In turn, Martinez-Pecino and Durán (2019) identified in a cross-sectional study greater practice of cyberbullying by men than by women, against their female partners. A study by the Chilean Superintendence of Education revealed that cyberbullying complaints in women increased by 82\% in Chilean schools (Soto \& Sanchez, 2019) and girls who practice sexting with their partners are generally more likely to suffer some form of cyberbullying in their relationship (Rodríguez-Castro et al., 2021).

\section{Conclusion}

In online violence, across all TFSV dimensions and categories identified, there is prevalence of victimization and greater negative impacts for women compared to men, with the exception of cyberbullying. Image-based sexual abuse was the most present TFSV Dimension in the review. This is a violence of public exposure that stands out and presents a contrast to traditional domestic violence occurring as a rule in the privacy of the home, an aspect on which we suggest further study. This finding reveals that women suffer serious violations in both private (domestic violence) and public (online violence) spaces, and that there is an urgent need for more knowledge about the problem in order to implement protection measures. In fact, when analyzing gender-based violence, it is not advisable to separate online from offline. Coercive sexting, for example, also a category related to image-based sexual abuse, has higher perpetration rates than offline sexual coercion and unwanted sexual intercourse itself.

A category belonging to the TFSV Dimension "image-based sexual abuse", revenge pornography is the category for which this review identified the largest number of studies addressing legal aspects. Despite this, this form of violence is still not sufficiently understood, since the phenomenon transcends the mere aspect of revenge of the "ex-lover".

Sexual agression and coercion facilitated by ICT has few empirical studies, which is why more investment in research is suggested. In abuse based on gender and sexuality, we highlight the alarming rates of anti-feminist violence on the Internet, contexts in which the police and judiciary do not demonstrate preparedness to face the events.

Digital dating abuse is one of the categories in which research clearly points to greater victimization of women compared to men. Suicide and suicidal ideation are serious consequences of DDA.

A low prevalence of studies on the legislation that regulates violence against women on the internet was observed. 
Results suggested a legislative vacuum that needs to be filled in order to fulfill the objectives of the 1993 Declaration on the Elimination of Violence against Women in the virtual environment. Research that identifies more effectively at what point is the regulation of the problem in the various nations and regions of the world would help in the development of public policies and indication of necessary actions for its minimization.

This research did not specifically focus on measures not related to the legal responsibility of the aggressors, i.e., focused on recommendations and good practices already adopted in dealing with violence against women on the internet. Thus, we understand that there is also the need to deepen this point in future studies, in parallel to the research about the legislations. Such studies can cover the actions to be adopted by groups of actors not only from the public powers, but also from the private sector and autonomous and community sectors.

It is hoped that this review has served as a stimulus for new research, and in this sense, it is suggested that future studies be conducted on online sexual harassment, gender-based hate speech, cyberbullying, sextortion, and online distribution of images of aggression, as well as further study of the relationship between offline and online violence against women. We also believe that comparative law studies and reviews of the measures already adopted to solve the problem are necessary

\section{References}

Agarwal, A. (2021). The case for treating violence against women as a form of sex discrimination in India. International Journal of Discrimination and the Law, 21(1), 5-25. DOI: 10.1177\%2F1358229120978865

Aizenkot, D., \& Kashy-Rosenbaum, G. (2021). Cyberbullying victimization in whatsapp classmate groups among israeli elementary, middle, and high school students. Journal of Interpersonal Violence, 36(15-16), NP8498-NP8519. DOI: 10.1177/0886260519842860

Andreasen, M. (2020). 'Rapeable' and 'unrapeable' women: the portrayal of sexual violence in Internet memes about \#MeToo. Journal of Gender Studies, 30(1), 102-113. DOI: 10.1080/09589236.2020.1833185

Blake, K., O’Dean, S., Lian, J., \& Delson, T. (2021). Misogynistic tweets correlate with violence against women. Psychological Science, 32(3), 315-325. DOI: $10.1177 \% 2$ F0956797620968529

Bonavitta, P., Preman, C., \& Becerra, J. (2020). Ciberfeminismo viejas luchas, nuevas estrategias: el escrache virtual como herramienta de acción y resistencia. Anagramas: Rumbos e Sentidos de la Comunicacion, 18(36), 327-333. DOI: 10.22395/angr.v18n36a9

Bond, E., \& Tyrrell, K. (2021). Understanding revenge pornography: a national survey of police officers and staff in England and Wales. Journal of Interpersonal Violence, 36(5-6), 2166-2181. DOI: 10.1177\%2F0886260518760011

Borrajo, E., Gámex-Guadix, M., \& Calvete, E. (2015). Justification beliefs of violence, myths about love and cyber dating abuse. Psichotema, 27(4), 327-333. DOI: $10.7334 /$ psicothema2015.59

Burnay, J., Bushman, B., \& Laroi, F. (2019). Effects of sexualized video games on online sexual harassment. Aggressive Behavior, 45(2), 214-223. DOI: $10.1002 / \mathrm{ab} .21811$

Cárdenas, F., Rojas-Solis, J., \& Garcia-Sanchéz, P. (2018). Uso problemático de internet, cyberbullying y ciber-violencia de pareja en jóvenes universitarios. Diversitas: Perspectivas em Psicología, 14(2), 205-219. DOI: 10.15332/s1794-9998

Cava, M., Buelga, S., Carrascosa, L., \& Ortega-Barón, J. (2020). Relations among romantic myths, offline dating violence victimization and cyber dating violence victimization in adolescents. International Journal of Environmental Research and Public Health, 17(5), 1551. DOI: 10.3390/ijerph17051551

Cerón, M., Eisman, L., \& Palomares, F. (2018). Grooming, cyberbullying and sexting in Chile according of sex and school management or administrative dependency. Revista Chilena de Pediatria, 89(3), 352-360. DOI: 10.4067/S0370-41062018005000201

Chisala-Tempelhoff, S., \& Kirya, M. (2016). Gender, law and revenge porn in Sub-Saharan Africa: a review of Malawi and Uganda. Palgrave Communications, 2, 16069. DOI: 10.1057/palcomms.2016.69

Codin Rights, \& InternetLab. (2017). Violências contra mulher na internet: diagnóstico, soluções e desafios contribuição conjunta do Brasil para a relatora especial da ONU sobre violência contra a mulher. São Paulo: Codin Rights. https://www.internetlab.org.br/wpcontent/uploads/2017/11/Relatorio_ViolenciaGenero_ONU.pdf

Cornelius, T., Bell, K., Kistler, T., \& Drouin, M. (2020). Consensual Sexting among College Students: the interplay of coercion and intimate partner aggression in perceived consequences of sexting. International Journal of Environmental Research and Public Health, 17(19), 7141. DOI: $10.3390 /$ ijerph17197141

Douglass, C., Wright, C., Davis, A., \& Lim, M. (2018). Correlates of in-person and technology-facilitated sexual harassment from an online survey among young Australians. Sexual Health, 15(4), 361-365. DOI: 10.1071/SH17208

Garcia, L., \& Silva, G. (2018). Violência por parceiro íntimo: perfil dos atendimentos em serviços de urgência e emergência nas capitais dos estados brasileiros, 2014. Cadernos de Saúde Pública, 30(4), e00062317. DOI: 10.1590/0102-311X00062317 
Garcia-Díaz, J., Cánovas-Garcia, M., \& Colomo-Palacios, R. (2021). Detecting misogyny in spanish tweets. an approach based on linguistics features and word embeddings. Future Generation Computer Systems, 114, 506-518. DOI: 10.1016/j.future.2020.08.032

Gius, C. (2021). Addressing the Blurred question of 'responsibility': insights from online news comments on a case of nonconsensual pornography. Journal of Gender Studies, 31(2), 193-203. DOI: 10.1080/09589236.2021.1892610

Gracia-Leiva, M., Puente-Martinez, A., Ubillos-Landa, S., González-Castro, J., \& Páez-Rovira, D. (2020). Off and online heterosexual dating violence, perceived attachment to parents and peers and suicide risk in young women. International Journal of Environment Research and Public Health, 17(9), 506518. DOI: 10.3390/ijerph17093174

Hellevik, P., \& Øverlien, C. (2016). Teenage intimate partner violence: factors associated with victimization among Norwegian youths. Scandinavian Journal of Public Health, 44(7), 702-708. DOI: 10.1177/1403494816657264

Henry, N., \& Flynn, A. (2019). Image-based sexual abuse: online distribution channels and illicit communities of support. Violence Against Women, 25(16), 1932-1955. DOI: $10.1177 / 1077801219863881$

Henry, N., \& Powell, A. (2018). Technology-facilitated sexual violence: a literature review of empirical research. Trauma, Violence and Abuse, 19(2), 195208. DOI: $10.1177 / 1524838016650189$

Henry, N., \& Powell, A. (2015). Embodied harms: gender, shame, and technology-facilitated sexual violence. Violence Against Womem, 21(6), 758-779. DOI: $10.1177 / 1077801215576581$

Hobbs, M., Owen, S., \& Gerber, L. (2017). Liquid love? Dating apps, sex, relationships and the digital transformation of intimacy. Journal of Sociology, 53(2), 271-284. DOI: 10.1177/1440783316662718

Htun, M., \& Jenseniu, F. R. (2020). Fighting violence against women: laws, norms \& challenges ahead. Daedalus, 149(1), 144-159. DOI: 10.1162/DAED_a_01779

Instituto Andaluz de Administración Pública. (2017). Redes sociales en perspectiva de género: guía para conocer y contrarrestrar las violencias de género on-line. Andaluzia: Junta de Andalucía.

Jesus, D., \& Milagre, J. A. (2016). Manual de crimes informáticos. São Paulo: Saraiva.

Lei $n^{\circ}$ 14.232, de 28 de outubro de 2021. (2021). Institui a Política Nacional de Dados e Informações relacionadas à Violência contra as Mulheres (PNAINFO). Brasília: Presidência da República. http://www.planalto.gov.br/ccivil03/Ato2019-2022/2021/Lei/L14232.htm.

Marcotte, A., Gesselman, A., Fisher, H., \& Garcia, J. (2020). Women's and men's reactions to receiving unsolicited genital images from men. Journal of Sex Research, 58(4), 512-521. DOI: 10.1080/00224499.2020.1779171

Martinez-Pecino, R., \& Durán, M. I love you but I cyberbully you: the role of hostile sexism. Journal of Interpersonal Violence, 34(4), 812-825. DOI: $10.1177 / 0886260516645817$

Medeiros, A., Lima, A., Bezerra, M., Silva, V., Cardoso, B., Rodrigues, A., \& Araújo, T. (2021). Challenge - o silêncio mata: mídias sociais e informação no combate à violência contra a mulher. Research, Society and Development, 10(9), e39710918066. DOI: 10.33448/rsd-v10i9.18066

Minayo, M. C. S. (2020). Conceitos, teorias e tipologias de violência: a violência faz mal à saúde. In: K. Njaine, S. G. Assis, P. Constantino, \& J. Q. Avanci. Impactos da Violência na Saúde (pp. 19-42). Rio de Janeiro: FIOCRUZ.

Montesanti, S. R. (2015). The role of structural and interpersonal violence in the lives of women: a conceptual shift in prevention of gender-based violence. BMC Women's Health, 15, 93. DOI: 10.1186/s12905-015-0247-5

Naseri, R., Hussin, H., Esa, M., Aziz, N., \& Nordin, M. (2021). What is a population in online shopping research? A perspective from Malaysia. Turkish Journal of Computer and Mathematics Education, 12(4), 654-658. DOI: 10.17762/turcomat.v12i4.549

Powell, A., \& Henry, N. (2019). Technology-facilitated sexual violence victimization: results from an online survey of Australian adults. Violence Against Women, 34(17), 3637-3665. DOI: 10.1177/0886260516672055

Reed, L., Wart, L., Tolman, R., Lipmann, J., \& Seabrook, R. (2018). The association between stereotypical gender and dating beliefs and digital dating abuse perpetration in adolescent dating relationships. Journal of Interpersonal Violence, 36(9-10), NP5561-NP5585. DOI: 10.1177/0886260518801933

Reed, L., Tolman, R., \& Ward, L. (2017). Gender matters: experiences and consequences of digital dating abuse victimization in adolescent dating relationships. Journal of Adolescence, 59, 79-89. DOI: 10.1016/j.adolescence.2017.05.015

Reed, L. A., Tolman R. M., Ward, L. (2016). Snooping and Sexting: digital media as a context for dating aggression and abuse among college students. Violence Against Women, 22(13), 1556-1576. DOI: 10.1177/1077801216630143

Remón, I., \& Medina-Bravo, P. (2018). Ciberviolencia en la red: nuevas formas de retórica disciplinaria en contra del feminismo. Papers, 104(1), 47-74. DOI: $10.5565 /$ rev/papers. 2390

Rodríguez-Castro, Y., Martinéz-Román, R., Alonso-Ruido, P., Adá-Lameiras, A., \& Carreira-Fernandez, M. (2021). Intimate partner cyberstalking, sexism, pornography, and sexting in adolescents: new challenges for sex education. International Journal of Environmental Research and Public Health, 18(4), 2181. DOI: 10.3390/ijerph18042181

Roichman, C. (2020). Faca, peixeira, canivete: uma análise da lei do feminicídio no Brasil. Revista Katálysis, 23(2), 357-365. DOI: 10.1590/1982$02592020 v 23 n 2 p 357$ 
Ross, J., Drouin, M., \& Coupe, A. (2019). Sexting coercion as a component of intimate partner polyvictimization. Journal of Interpersonal Violence, 34(11), 2269-2291. DOI: 10.1177/0886260516660300

Rubio-Laborda, J., Almansa-Martínez, P., \& Pastor-Bravo, M. (2021). Relaciones sexistas en la generación X y Millennials. Atención Primaria, 53(4), 101992. DOI: 10.1016/j.aprim.2021.101992

Ruiz, J., Valente, M., \& Neris, N. (2019). Entre el perpetrador y la víctima: el papel de los intermediarios de Internet en las violaciones contra las mujeres. Sociologia y Tecnociencia, 9(1), 9-27. DOI: 10.24197/st.1.2019.9-27

Sambasivan, N., Batool, A., Ahmed, N., Matthews, T., Thomas, K., Gaytán-Lugo, L., Nemer, D., Bursztein, E., Churchill, E., \& Consolvo, S. (2019). “They don't leave us alone anywhere we go": gender and digital abuse in South Asia. New York: CHI. DOI: 10.1145/3290605.3300232

Sánchez, O., Vale, D., Rodrigues, L., \& Surita, F. (2020). Violence against women during the COVID-19 pandemic: an integrative review. International Journal of Ginecology Obstetrics, 151(2), 180-187. DOI: 10.1002/ijgo.13365

Selaimen, G. (2013). Mulheres desenvolvedoras de tecnologias - o desafio das histórias invisíveis que moram entre zeros e uns. In: G. Natansohn. Internet em código feminino: teorias e práticas (pp.161-179). Buenos Aires: La Crujía Ediciones.

Silva, M. (2016). A pornografia de vingança e os desafios da proteção da privacidade online. JusBrasil. https://mfdpsilva.jusbrasil.com.br/artigos/407311374/a-pornografia-de-vinganca-e-os-desafios-da-protecao-da-privacidade-online?ref=topic_feed

Skinner, T., Hester, M., \& Malos, E. (2012). Methodology, feminism and gender violence. In: T. Skinner, M. Hester, \& E. Malos. Researching gender violence (pp. 2-3). Feminist methodology in action. Abingdon: Routledger.

Soto, C., \& Sanchez, K. (2019). Violencia en internet contra feministas y otras activistas chilenas. Revista Estudos Feministas, 27(3), e58797. DOI: $10.1590 / 1806-9584-2019 v 27 n 358797$

Soto, C. (2018). Discurso de los lectores de medios digitales ante la violencia policial contra la mujer: ¿otra forma de violencia virtual? Estudios Sobre el Mensaje Periodístico, 24(2), 1023-1041. DOI: 10.5209/ESMP.62200

Stanley, N., Barter, C., Wood, M., Aghtaie, N., Larkins, C., Lanau, A., \& Överlien, C. (2018). Pornography, sexual coercion and abuse and sexting in young people's intimate relationships: a european study. Journal of Interpersonal Violence, 33(19), 2919-2944. DOI: 10.1177/0886260516633204

Stonard, K. E., Bowen, E., Walker, K., \& Price, S. (2017). “They'll always find a way to get to you": technology use in adolescent romantic relationships and its role in dating violence and abuse in dating violence and abuse. Journal of Interpersonal Violence, 32(14), 2083-2117. DOI: 10.1177/0886260515590787

Tetikcok, R., Ozer, E., Cakir, L., Enginyurt, O., Iscanli, M. D., Cankaya, S., \& Ozer, F. (2016). Violence towards women is a public health problem. Journal of Forensic and Legal Medicine, 44, 150-157. DOI: 10.1016/j.jflm.2016.10.009

Toronto, C., \& Remington, R. (2020). A step-by-step guide to conducting an integrative review. New York: Springer.

United Nations. (1993). Resolution adopted by the general assembly 48/104. Declaration on the elimination of violence against women. New York: United Nations. http://www.un-documents.net/a48r104.htm

White, M., \& Satyen, L. (2015). Cross-cultural differences in intimate partner violence and depression: a systematic review. Agression and Violent Behavior, 24, 120-130. DOI: 10.1016/j.avb.2015.05.005

Whitemore, R., \& Knalf, K. (2005). The integrative review: update methodology. Journal of Advanced Nursing, 52(5), 546-553. DOI: 10.1111/j.13652648.2005.03621.x

Zhong, L. R., Kebell, M. R., \& Webster, J. L. (2020). An exploratory study of technology-facilitated sexual violence in online romantic interactions: can the internet's toxic disinhibition exacerbate sexual aggression? Computer in Human Behavior, 108, 106314. DOI: 10.1016/j.chb.2020.106314

Zúñiga, R. P., Lozano, P. M., García, M. M., Hernández, E. M., \& Ibarra, J. Á. P. (2018). La sociedad del conocimiento y la sociedad de la información como la piedra angular en la innovación tecnológica educativa. RIDE. Revista Iberoamericana para la Investigación y el Desarrollo Educativo, 8(16), 847-870. DOI: $10.23913 /$ ride.v8i16.371 